\title{
ANALISA PEMASANGAN FILTER HYBRID TERHADAP BEBAN-BEBAN NON LINIER PADA BLUE POINT BAY VILLA DAN SPA
}

\author{
I Wayan Dedy Setiawan ${ }^{1}$, I Wayan Rinas ${ }^{2}$, Antonius lbi Weking ${ }^{3}$ \\ 1,2,3 Jurusan Teknik Elektro dan Komputer Fakultas Teknik Universitas Udayana \\ Email:dedysetiawan730@gmail.com ${ }^{1}$, rinas@unud.ac.id $^{2}$, tony@ee.unud.ac.id ${ }^{3}$
}

\begin{abstract}
ABSTRAK
Kajian sebelumnya tentang analisa harmonisa telah dilakukan di hotel The Blue Point Bay Villa \& Spa yaitu banyak terdapat tinggginya kandungan beban-beban non linier yang mengakibatkan adanya distorsi harmonisa yang berdampak pada rugi-rugi daya. Kandungan harmonisa arus pada sistem kelistrikan di hotel The Blue Point Bay Villa \& Spa tidak memenuhi standar IEEE 519-1992 yang mengakibatkan kualitas daya menurun. Penelitian ini menganalisis langkah-langkah pemasangan filter hybrid type high-pass untuk meredam distorsi harmonisa, menganalisis daya losses menggunakan software ETAP. Analisis dilakukan sebelum dan sesudah pemasangan filter hybrid. Hasil analisis dari simulasi filter hybrid dapat mereduksi distorsi harmonisa dengan nilai $T H D_{i}$ pada SDP1 sebesar 6,42 \%, SDP2 sebesar $6,41 \%$, SDP3 sebesar 6,42 \%, SDP4 sebesar $6.41 \%$, dan SDP5 sebesar $6.42 \%$. Nilai $T H D_{v}$ hasil simulasi pada semua SDP sebelum pemasangan filter hybrid yaitu $8,80 \%$ dan sesudah pemasangan filter hybrid yaitu $0,13 \%$.
\end{abstract}

Kata kunci : Beban non linier, Harmonisa, THD, filter aktif high-pass

\begin{abstract}
A previous review of harmonic analyzes has been conducted at The Blue Point Bay Villa \& Spa hotel, where there are many high non linear loads, resulting in harmonic distortions that have an impact on power losses. The current harmonic content of the electricity system at The Blue Point Bay Villa \& Spa hotel does not meet the IEEE 519-1992 standard which results in decreased power quality. This research analyzes the steps of installing high-pass hybrid filter type to reduce harmonic distortion, analyze power losses using ETAP software. Analysis is performed before and after the installation of hybrid filters. The analysis result of hybrid filter simulation can reduce harmonic distortion with THDi value at SDP1 equal to 6,42\%, SDP2 equal to $6,41 \%$, SDP3 equal to $6,42 \%$, SDP4 6,41\%, and SDP5 6,42\%. THDv value simulation results on all SDP before installation of hybrid filter that is $8.80 \%$ and after installation of hybrid filter that is $0,13 \%$.
\end{abstract}

Keywords : non-linear Loads, Harmonics, THD, high-pass active filter.

\section{PENDAHULUAN}

Perkembangan kecanggihan teknologi digital yang sangat pesat akan membawa perubahan terdapat banyak di kehidupan manusia. Kebanyakan peralatan - peralatan listrik, bahkan hampir semua peralatan listrik yang ada saat ini berbasis mikro elektronik. Peralatan jenis ini merupakan jenis beban non linier, dimana bentuk gelombang arus dan tegangan yang keluaranya tidak sebanding dengan gelombang masukannya di kenal sebagai harmonisa [1][2]. Pengoperasian peralatan elektronika daya yang menimbulkan distorsi pada bentuk arus gelombang listrik dengan daya losses minimum pada frekuensi fundamentalnya. Tingkat harmonisa yang tinggi sangat banyak berpengaruh pada transformator, sehingga akan terjadi (losses) [3].

Latar belakang tersebut diatas, maka pada tugas akhir ini akan dilakukan analisis mengenai pengaruh pengoperasian filter hybrid yang merupakan penggabungan filer pasif dengan filter aktif yang dikonfigurasikan seri. Penggunaan filter diharapkan agar meningkatkan kinerja filter pasif terhadap distorsi harmonisa di Bay Villa \& 
SPA, dengan menggunakan software ETAP.

\section{KAJIAN PUSTAKA}

Kajian pustaka mencakup teori-teori penunjang yang dijadikan acuan yang meliputi pemasangan filter hybrid terhadap beban-baban non linier.

\subsection{Harmonisa}

Harmonisa adalah gelombang arus sinusoidal memiliki frekuensi yang merupakan hasil kali interger dari frekuensi dasar dimana suplai sistem dirancang untuk beroperasi antara 50 atau $60 \mathrm{~Hz}$. Gelombang Harmonisa disebabkan oleh adanya beban nonlinear yang digunakan dalam sistem tenaga. Dalam pemanfaatan filter harmonisa ini adalah untuk meredam pengaruh harmonic maka pada transformator distribusi atau panel control utama perlu dipasang peralatan proteksi ,antara lain filter harmonisa baik filter aktif atau filter pasif. Tujuan utama dari filter harmonisa adalah untuk mengurangi amplitude dari sebuah tegangan arus pada frekuensi tertentu [4].

\subsection{Beban Nonlinier}

Peralatan yang dihasilkan oleh gelombang arus yang tidak proporsional berbentuk sinusoidal berfrekuensi tinggi disebut dengan arus harmonisa dinamakan beban non linier, lihat pada Gambar 1. Hasil yang ditimbulkan oleh arus harmonisa pada peralatan sistem tenaga listrik yaitu implikasi, misalnya pemanasan berlebih pada kapasitor, rugi-rugi pada jaringan akan meningkat, kesalahan pada percobaan alat ukur, pada mesin yang berputar dan transformator.

Sebagian besar beban nonlinier yang digolongkan deforming loads adalah konverter statis. Beban ini dapat berdaya besar dengan jumlah yang sedikit atau berdaya rendah dengan hasil jumlah yang banyak [1].

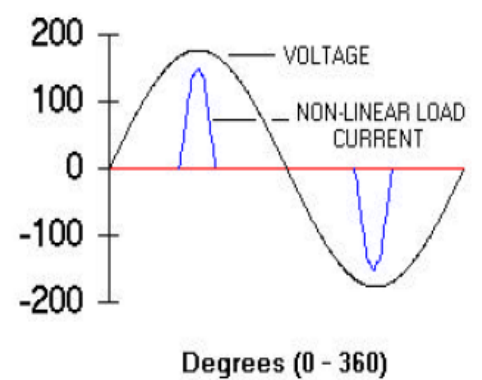

Gambar 1. Gelombang Arus dan Tegangan Beban Non Linier [1]

\subsection{Beban Linier}

Sedangkan beban linier yaitu kebalikanya dari beban non linier beban impedansi yang selalu konstan sehingga arus selalu berbanding lurus dengan tegangan setiap waktu. Terdapat hubungan yang linier antara arus dan tegangan sehingga bentuk gelombang arus akan sama dengan bentuk gelombang teganganya pada Gambar 2. Gelombang arus dan tegangan yang dihasilkan oleh beban linier komponen arusnya proposional terhadap bentuk gelombang teganganya, apabila diberi tegangan sinusiodal, maka arus mengalir ke beban linier merupakan arus yang sama juga sehingga tidak menimbulkan distorsi [1].

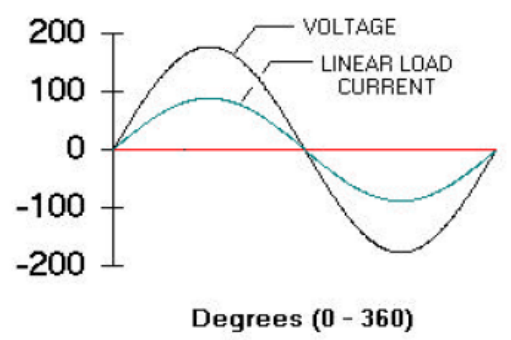

Gambar 2. Bentuk Gelombang Arus dan Tegangan Beban Linier [1].

\subsection{Pemodelan Pemasangan Filter Hybrid}

Perencanaan filter hybrid dimodelkan dalam bentuk kombinasi antara pemasangan filter aktif dan filter pasif. Hal ini bertujuan untuk mencegah meluasnya tegangan harmonisa. Pemasangan filter hybrid yang terdiri dari filter aktif seri dan filter pasif shunt dipasang secara bersamaan seperti Gambar 3. Filter aktif dipasang seri dengan beban non linear sedangkan filter pasif dipasang secara pararel terhadap beban non linear.

Prinsip dasar Filter aktif adalah, seperti inverter yang dikontrol secara khusus dan secara aktif dapat mendeteksi komponen arus spesifik di jaringan. Mengunakan dengan cara sederhana yaitu menyuntikkan arus harmonisa yang fasanya dibuat berbeda, sehingga saling menghilangkan yang tujuannya untuk menggagalkan daya arus harmonisa menuju sumber filter aktif juga dapat mengkompensasi faktor daya atau fungsi yang lain. Berbeda dengan filter pasif yang hanya dapat memfilter satu harmonisa pada satu link filter pasif, filter aktif bias mengkompensasi banyak harmonisa hanya dengan satu link filter aktif [5]. 


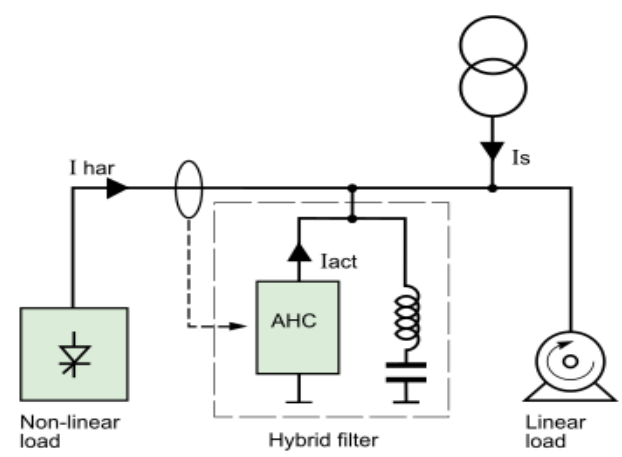

Gambar 3. Rangkaian Hybrid Active Filter [5].

\section{METODOLOGI PENELITIAN}

Metodologi yang digunakan dalam pemasangan filter hybrid terhadap bebanbeban non linier ini mempunyai langkahkah sebagai berikut ditunjukan pada Gambar 4 .

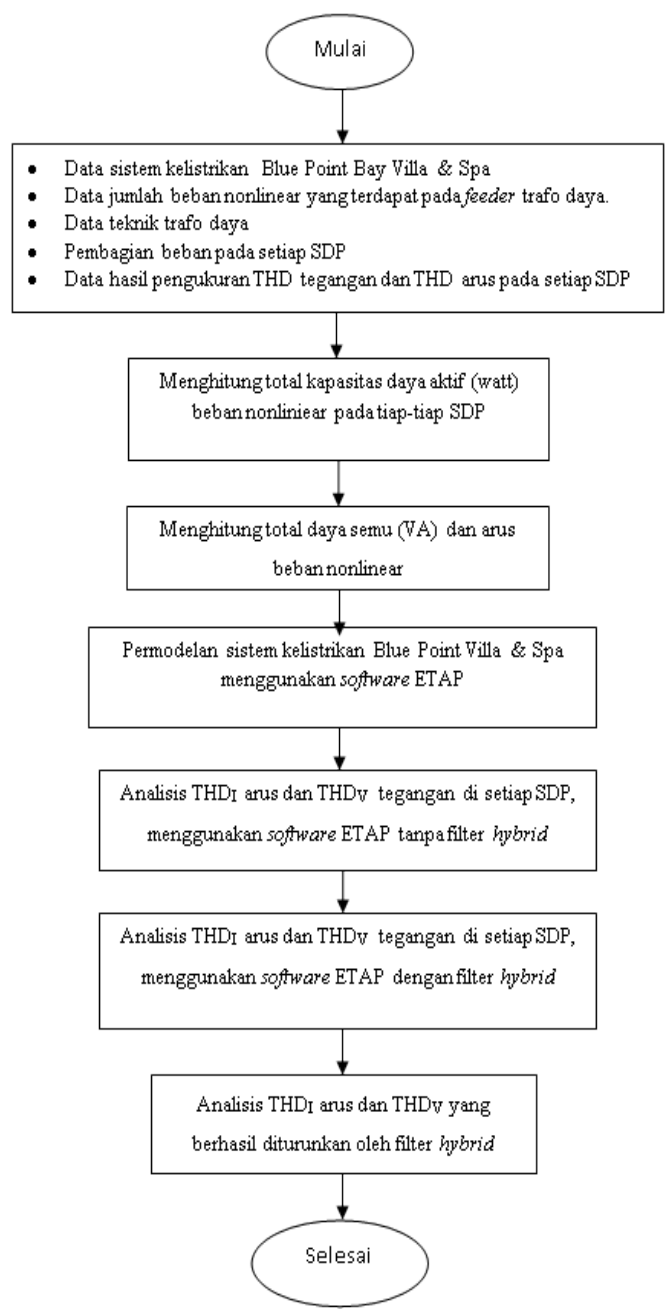

Gambar 4. Flowchart Alur Analisis

\subsection{Sumber Data}

Sumber data yang digunakan dalam penelitian Tugas Akhir ini berupa data pri- mer yang diperoleh dari pengukuran bebanbeban yang dioperasikan di The Blue Point Bay Villa \& SPA dan studi literatur yang berkaitan dengan tema pembahasan.

\subsection{Analisa Data}

1. Pengumpulan data sistem kelistrikan single line diagram di The Blue Point Bay Villa \& SPA, data kapasitor dan jumlah beban nonlinear yang terdapat pada feeder trafo daya dan data hasil pengukuran dari THDi dan THDV Menghitung total kapasitas daya aktif (watt) beban nonliniear pada tiap-tiap panel.

2. Menghitung total kapasitas daya semu (VA) dan arus beban nonlinear pada tiap-tiap panel.

3. Menghitung total daya semu (VA) dan arus beban nonlinier pada tiap-tiap panel.

4. Batas maksimum $T H D_{l}$ dan $T H D_{V}$ berdasarkan IEEE standar 519-1992 [6].

5. Permodelan sistem kelistrikan di The Blue Point Bay Villa \& SPA dengan menggunakan software ETAP.

6. Analisis $T H D_{1}$ dan $T H D_{V}$ dengan melakukan simulasi menggunakan software ETAP tanpa filter hybrid.

7. Analisis $T H D_{1}$ dan $T H D_{V}$ dengan melakukan simulasi menggunakan software ETAP dengan filter hybrid.

8. Analisis hasil simulasi berdasarkan IEEE standar 519-1992 [6]

\section{HASIL DAN PEMBAHASAN}

4.1 Sistem Kelistrikan Blue Point Bay Villa \& SPA

Blue Point Bay Villa \& Spa merupakan salah satu hotel bintang 3 yang terletak di jalan Uluwatu Jimbaran-Bali. Berikut ini merupakan data karakteristik trafo di The Blue Point Bay Villa \& Spa ditunjukan pada Tabel 1 .

Tabel 1 Data Karakteristik Transformator Distribusi The Blue Point Bay Villa \& Spa

\begin{tabular}{|c|c|}
\hline Daya & $630 \mathrm{Kva}$ \\
\hline Phasa & 3 \\
\hline Tegangan Primer (Kv) & $20 \mathrm{Kv}$ \\
\hline Tegangan Sekunder (Kv) & $400 / 231 \mathrm{~V}$ \\
\hline Vektor Group & DyN5 \\
\hline Impedansi (\%) & $4 \%$ \\
\hline $\mathrm{R}$ & $1,03 \%$ \\
\hline $\mathrm{X}$ & $3,86 \%$ \\
\hline
\end{tabular}

Sumber: The Blue Point Bay Villa \& Spa [7][8] 


\subsection{Kapasitas Daya Aktif, Daya Semu dan Arus Beban Non Linier pada Setiap SDP \\ Daya aktif yang terpasang pada SDP} 1.1 dimana phasa R: 9156 watt, S: 9998 watt, dan T: 9170 watt. Besarnya $(\operatorname{Cos} \theta)$ factor daya yang di dapat dari hasil pengukuran tiap panel pada sistem kelistrikan The Blue Point Bay Villa \& Spa yaitu 0.85. Dapat dihitung besar total daya semu (VA) perphasa dan arus beban-beban nonlinier yaitu :

$$
\text { Daya Semu Phasa } \begin{aligned}
R & =\frac{\text { Daya Aktif }(\text { Watt })}{\operatorname{Cos} \theta} \\
& =\frac{9156}{0,85}=10,77 \mathrm{kVA}
\end{aligned}
$$

Arus beban nonlinier $\left(I_{\mathrm{NL}}\right)$ phasa $\mathrm{R}=$

$$
\begin{aligned}
& I_{N L}=\frac{\text { Daya Aktif }(\mathrm{W})}{\mathrm{V}_{\text {sistem }}(\mathrm{V}) \cdot \mathrm{pf}} \text {, diketahui } \mathrm{pf}=0,85 \\
& =\frac{9156}{187}=48,96 \mathrm{~A} \\
& I S C=\frac{k V A \cdot 100}{\sqrt{3} \cdot K V \cdot Z(\%)} \\
& =\frac{10,77 \cdot 100}{\sqrt{3} \cdot 04 \cdot 4} \\
& =\frac{1077}{2,8}=384,6 \mathrm{~A} \\
& S C_{\text {ratio }}=\frac{I S C}{I L}=\frac{384,6}{48,96}=7,8 \mathrm{~A}
\end{aligned}
$$

\subsection{Hasil Simulasi Sebelum Peng- operasian Filter Hybrid}

Dapat dilihat pada Gambar 5 dan Gambar 6 bahwa terjadinya cacat distorsi terhadap bentuk grafik dan gelombang tegangan yang tidak beraturan diakibatkan adanya beban non linier pada sistem kelistrikan tersebut.

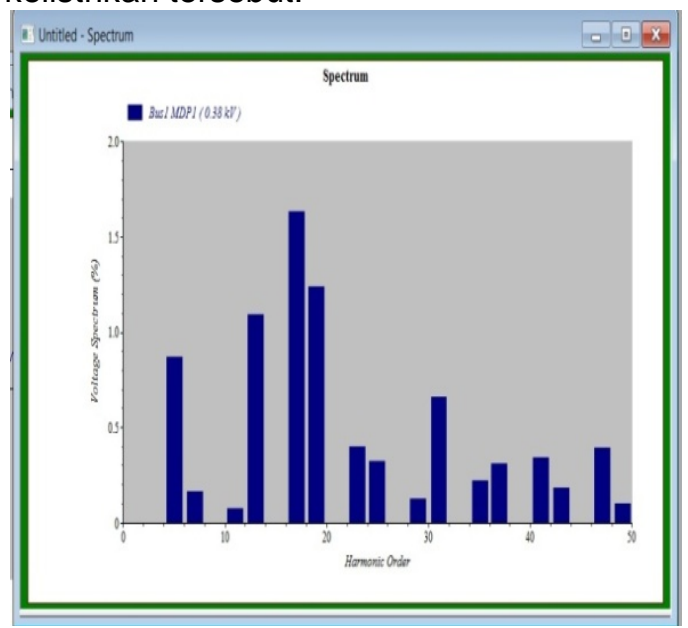

Gambar 5. Running Spektrum Sebelum Pemasangan Filter Hybrid pada Sistem

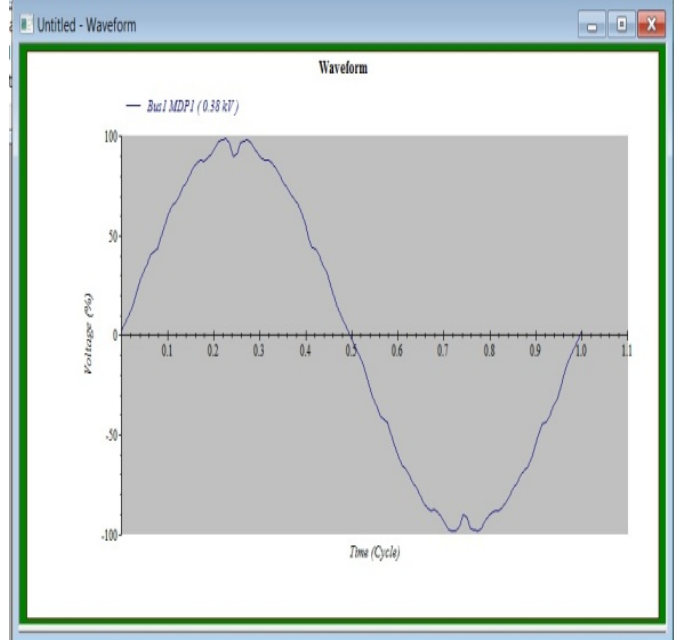

Gambar 6. Running Gelombang Sebelum Pemasangan Filter Hybrid pada Sistem

\subsection{Simulasi Penggunaan Filter Hybrid}

\subsubsection{Perancangan Filter Aktif untuk} Meredam Distorsi Harmonisa

Filter yang akan digunakan untuk meredam distorsi harmonisa adalah filter aktif type hight-pass (damped). Perancangan filter aktif hight-pass bertujuan untuk meredam distorsi harmonisa yang timbul akibat adanya beban non linier, kemudian selain itu dapat memperbaiki faktor daya karena adanya komponen kapasitor dalam filter. Perhitungan akan dilakukan pada MDP yang memiliki distorsi harmonisa arus terbesar yaitu sebesar $25,17 \%$. Terlebih dahulu harus menentukan orde harmonisa yang akan dieliminasi yaitu terletak pada orde ke 5 karena pada orde tersebut terdapat distorsi terbesar.

$$
\begin{aligned}
& P=190672,5 \mathrm{Watt}=190,672 \mathrm{~kW} \\
& \theta_{1}=\operatorname{Arc} \cos 0,85=31,78^{\circ} \\
& \theta_{2}=\operatorname{Arc} \cos 0,98=11,47 \\
& \theta_{c}=P\left(\tan \theta_{1}-\theta_{2}\right) \\
& \theta_{c}=190672,5\left(\tan 31,78^{\circ}-\tan 11,47^{\circ}\right) \\
& \theta_{c}=80,80 \mathrm{kVar}
\end{aligned}
$$

Rating kapasitor (dalam Farad) komponen filter adalah, menggunakan perhitungan dibawah ini :

$$
\begin{aligned}
& Q c=\frac{Q c}{w \cdot v^{2}}=\frac{80,08}{(314,16)(0,4)^{2}}=\frac{80,08}{50,26}=1,59 F \\
& X_{c}=\frac{v^{2}}{Q_{c}}=\frac{0,4^{2}}{1,59}=0,1 \Omega \\
& C=\frac{1}{2 \pi f X c}=\frac{1}{(2 \times 3,14)(50)(0,1)}=0,0003 \mathrm{~F}
\end{aligned}
$$


Frekuensi Tuning $=250 \mathrm{~Hz}$ (orde 5)

Maka, komponen reaktor filter mengguna kan perhitungan sebagai berikut :

$$
\begin{aligned}
& L=\frac{1}{(c)(2 \pi f x c)^{2}}=\frac{1}{(0,0003)(2 \times 3,14 \times 50 \times 5)^{2}} \\
& L=\frac{1}{739,47}=0,0013 \mathrm{mH} \\
& X_{L}=2 \pi f L=\frac{1}{(2)(3,14)(50)(1,3)}=0,024 \Omega
\end{aligned}
$$

dan komponen resistansi filternya adalah ,mengunakan perhitungan dibawah ini :

$$
\begin{aligned}
Q & =\frac{R}{X_{L}} \\
R & =Q X_{L} \\
& =(45) \cdot(0,024) \\
& =1,08 \Omega
\end{aligned}
$$

$C$ adalah kapasistor

$$
C=1590 \mathrm{~m} F
$$$$
L \text { adalah induktor } \quad L=0.0013 \mathrm{mH}
$$$$
R \text { adalah resistor } \quad R=1,08 \Omega
$$

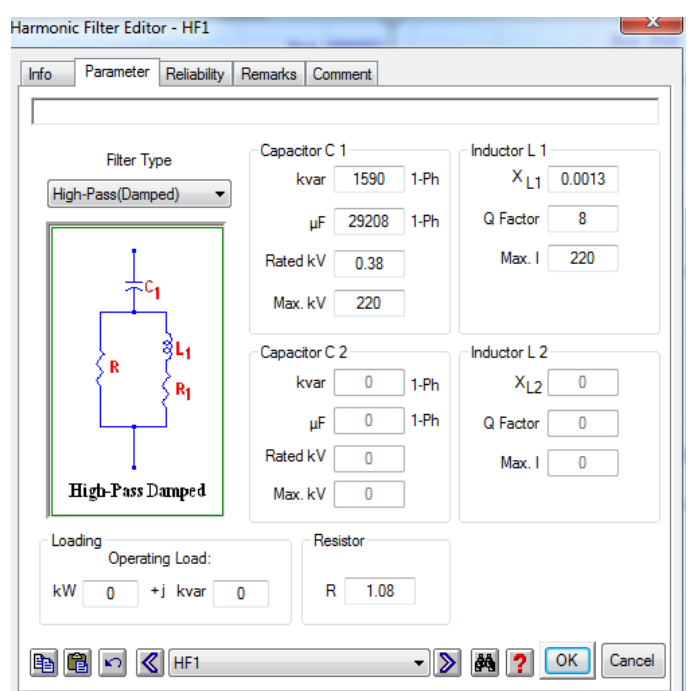

Gambar 7. Spesifikasi Filter Aktif

Diketahui nilai kapasitor seperti yang didapat dalam perhitugan nilai kVar dari kapasitor dimasukan dalam simulasi yaitu 159 dan rate $k V$ yaitu 0.38. Demikian juga nilai $X_{L}$ dari induktor dan nilai $Q$ faktornya yaitu 0.024 dan 45 . Serta nilai resistor filter yaitu $1,08 \Omega$.

\subsubsection{Perancangan Filter Pasif untuk Meredam Distorsi Harmonisa}

Berikut adalah perhitungan filter pasif harmonic, single tune orde ke-5

$$
V \operatorname{Ln}=\frac{400}{\sqrt{3}}=0,23 \mathrm{kV}
$$

Frekuensi sudut,

$\omega=2 . \pi . f=2(3,14) .50=314,16$

$Q=45$

$Q c=43,28 \mathrm{kVar}$

Rating kapasitor (dalam Farad) komponen filter adalah

$C=\frac{Q}{\omega \cdot v^{2}}=\frac{80,08}{(314,16) \cdot(0,23)^{2}}=\frac{80,08}{16,62}=4,82 \mathrm{~F}$

Frekuensi Tuning $=250 \mathrm{~Hz}$ (orde 5)

Maka, komponen reaktor filter

$$
\begin{gathered}
L=\frac{1}{(L) \cdot(\omega \cdot \mathrm{n})}=\frac{1}{(4,82)(314 \times 5)^{2}}=\frac{1}{11892928,92}=0,08 \mathrm{mH} \\
X_{L}=\omega \cdot L=(314) \cdot(0,00008)=0,025 \Omega \\
Q=\frac{n \cdot X_{L}}{R} \\
R=\frac{n \cdot X_{L}}{Q}=\frac{(5) \cdot(0,025)}{45}=2,7 \Omega
\end{gathered}
$$

$C$ adalah kapasistor $\quad C=4820 \mathrm{~m} F$ $L$ adalah induktor $\quad L=0,08 \mathrm{mH}$ $R$ adalah resistor $\quad R=2,7 \Omega$

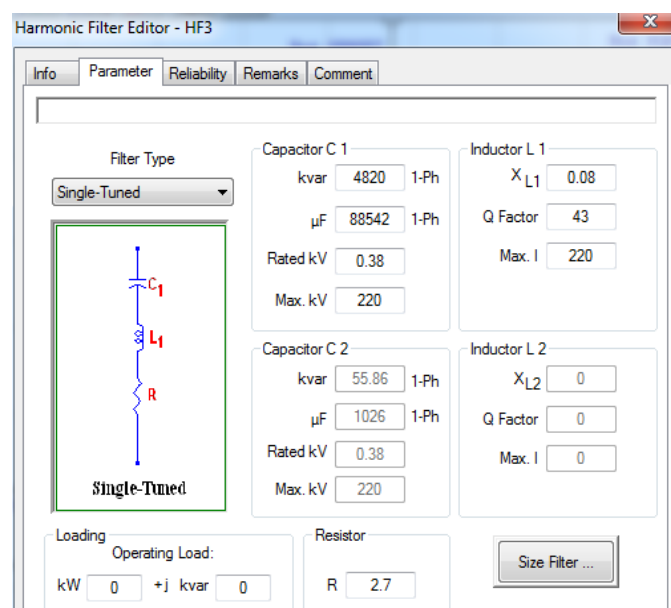

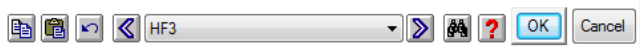

Gambar 8. Spesifikasi Filter Pasif

Diketahui nilai kapasitor seperti yang didapat dalam perhitugan nilai $k$ Var dari kapasitor dimasukan dalam simulasi yaitu 4820 dan rate $k V$ yaitu 0.38 . Demikian juga nilai $X_{L}$ dari induktor dan nilai $Q$ faktornya yaitu 0.08 dan 45 . Serta nilai resistor filter yaitu $2,7 \Omega$.

Tegangan line-netral. 


\subsection{Hasil Simulasi dengan Meng- gunakan Filter Hybrid}

Dapat dilihat pada Gambar 9 dan Gambar 10 bahwa cacat terhadap bentuk grafik dan gelombang tegangan yang diakibatkan adanya beban non linier pada sistem kelistrikan tersebut sudah bisa diredam dan lebih stabil oleh adanya pemasangan filter hybrid.

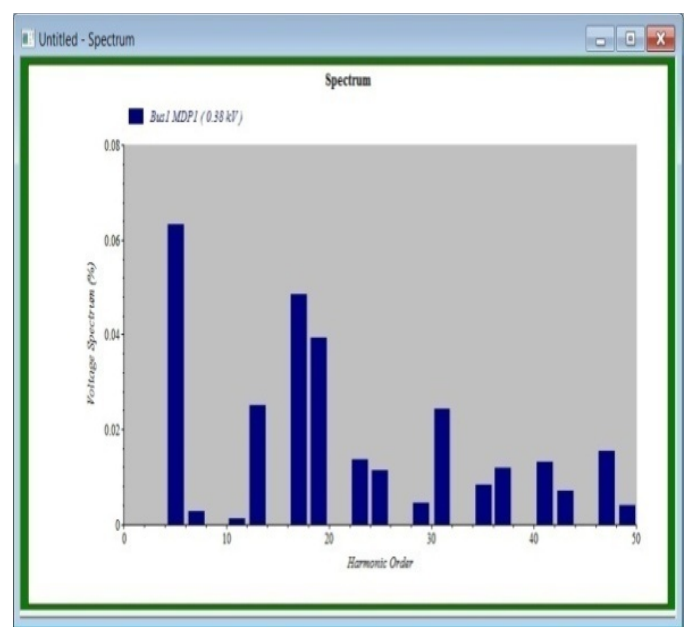

Gambar 9. Running Spektrum Setelah Pemasangan Filter Hybrid Pada Sistem

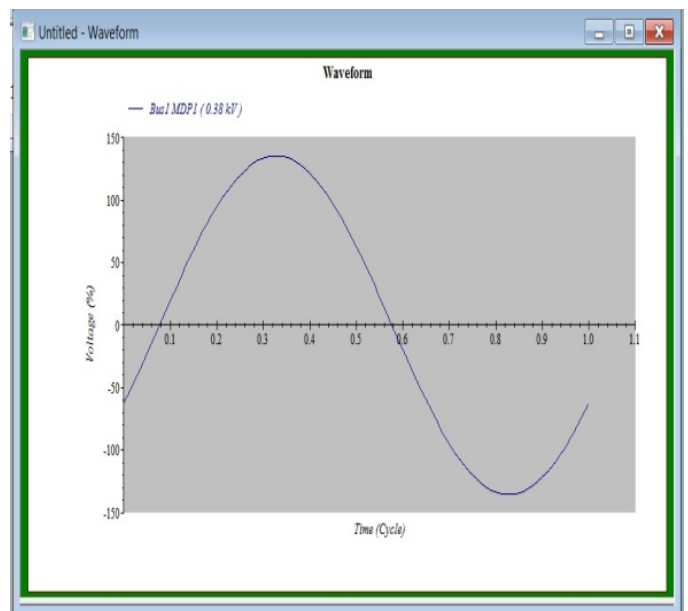

Gambar 10. Running Gelombang Setelah Pemasangan Filter Hybrid pada Sistem

\subsection{Analisis Penurunan THD, dan $\mathrm{THD}_{\mathrm{v}}$ Menggunakan Filter Hybrid Pada Blue Point Villa \& Spa \\ 4.6.1 Penurunan THD, Menggunakan Filter Hybrid Pada Blue Point Villa \& Spa}

Table. 2 menunjukan nilai $T H D$, hasil running dengan mengunakan filter hybrid sudah memenuhi standar IEEE 519-1992, yaitu seluruh SDP memiliki persentase $T H D$, dibawah $8 \%$
Tabel 2. Perbandingan $T H D_{I}$ Antara Sebelum dan Sesudah Pemasangan Filter Hybrid

\begin{tabular}{|c|c|c|c|c|c|c|}
\hline \multirow[t]{2}{*}{ No. } & \multirow[t]{2}{*}{ Tempat } & \multicolumn{2}{|c|}{ Hasil Runing } & \multirow[t]{2}{*}{ Keterangan } & \multirow{2}{*}{$\begin{array}{c}1992 \\
\text { stand ar IEEE 519. }\end{array}$} & \multirow{2}{*}{$\begin{array}{l}\text { Kompensasi } \\
\text { penvrunan } \\
\text { filter wobrid }\end{array}$} \\
\hline & & Sebelum & Sesudah & & & \\
\hline 1 & $\begin{array}{l}\text { SDP } \\
1.1 \\
\end{array}$ & $89,94 \%$ & $6,42 \%$ & $\mathrm{I}<8,0 \%$ & $\begin{array}{l}\text { Sudah Memernhi } \\
\text { Standar }\end{array}$ & $2.52 \%$ \\
\hline 2 & $\begin{array}{l}\text { SDP } \\
1.2 \\
\end{array}$ & $8,94 \%$ & $6,41 \%$ & $\mathrm{I}<8,0 \%$ & $\begin{array}{l}\text { Sudah Mementhi } \\
\text { Standar } \\
\end{array}$ & $2,53 \%$ \\
\hline 3 & $\begin{array}{l}\text { SDP } \\
1.3\end{array}$ & $8,94 \%$ & $6,42 \%$ & I $<8,0 \%$ & $\begin{array}{l}\text { Sudah Mementi } \\
\text { Standar }\end{array}$ & $2,52 \%$ \\
\hline 4 & $\begin{array}{l}\text { SDP } \\
1.4\end{array}$ & $893 \%$ & $6,41 \%$ & $\mathrm{I}<8.0 \%$ & $\begin{array}{l}\text { Sudah Memerwhi } \\
\text { Standar }\end{array}$ & $2,5 \%$ \\
\hline 5 & $\begin{array}{l}\text { SDP } \\
1.5\end{array}$ & $19,48 \%$ & $6,42 \%$ & I $<8,0 \%$ & $\begin{array}{l}\text { Sudah Memerwhi } \\
\text { Standar }\end{array}$ & $2,52 \%$ \\
\hline 6 & $\begin{array}{l}\text { SDP } \\
2.1\end{array}$ & $8.81 \%$ & $7,38 \%$ & $\mathrm{I}<8.0 \%$ & $\begin{array}{l}\text { Sudah Memenuhi } \\
\text { Standar }\end{array}$ & $1.43 \%$ \\
\hline 7 & $\begin{array}{l}\text { SDP } \\
2.2 \\
\end{array}$ & $8,82 \%$ & $7,38 \%$ & $\mathrm{I}<8,0 \%$ & $\begin{array}{l}\text { Sudah Mememini } \\
\text { Stzndar } \\
\end{array}$ & $1,44 \%$ \\
\hline 8 & $\begin{array}{l}\text { SDP } \\
2.3\end{array}$ & $8,83 \%$ & $7,38 \%$ & $\mathrm{I}<8,0 \%$ & $\begin{array}{l}\text { Sudah Mememhi } \\
\text { Standar }\end{array}$ & $1,55 \%$ \\
\hline
\end{tabular}

\subsubsection{Penurunan $T H D_{v}$ dengan Meng- gunakan Filter Hybrid Pada Blue Point Villa \& Spa}

Table 3 menunjukan nilai $\mathrm{THD}_{\mathrm{v}}$ hasil running dengan menggunakan filter hybrid sudah memenuhi standar IEEE 519-1992 yaitu seluruh SDP memiliki persentase THD, dibawah 5\%.

Tabel 3. Perbandingan $T H D_{v}$ Antara Sebelum dan Sesudah Pemasangan Filter Hybrid

\begin{tabular}{|c|c|c|c|c|c|c|}
\hline \multirow{2}{*}{ No. } & \multirow[b]{2}{*}{ Tempat } & \multicolumn{2}{|c|}{ HasilRuning } & \multirow[b]{2}{*}{ Keterang an } & \multirow{2}{*}{$\begin{array}{c}\text { standar } \mathbb{Z E E E} 519 . \\
1992\end{array}$} & \multirow{2}{*}{$\begin{array}{l}\text { Kompens asi } \\
\text { pempronan } \\
\text { filter hibrid }\end{array}$} \\
\hline & & Sebelum & Sesudah & & & \\
\hline 1 & $\begin{array}{l}\text { SDP } \\
1.1\end{array}$ & $2,82 \%$ & $0,13 \%$ & $V<5,0 \%$ & $\begin{array}{l}\text { SudahMemenuhi } \\
\text { Standar }\end{array}$ & $2,69 \%$ \\
\hline 2 & $\begin{array}{l}\text { SDP } \\
1.2 \\
\end{array}$ & $2,77 \%$ & $0,09 \%$ & $\mathrm{~V}<5,0 \%$ & $\begin{array}{l}\text { SudahMemenuhi } \\
\text { Standar } \\
\end{array}$ & $2,68 \%$ \\
\hline 3 & $\begin{array}{l}\text { SDP } \\
1.3\end{array}$ & $2,83 \%$ & $0,13 \%$ & $\mathrm{~V}<5,0 \%$ & $\begin{array}{l}\text { SudahMemenuhi } \\
\text { Standar }\end{array}$ & $2,7 \%$ \\
\hline 4 & $\begin{array}{l}\text { SDP } \\
1.4 \\
\end{array}$ & $2,72 \%$ & $0,07 \%$ & $\mathrm{~V}, 5,0 \%$ & $\begin{array}{l}\text { SudahMemenuhi } \\
\text { Standar } \\
\end{array}$ & $2,65 \%$ \\
\hline 5 & $\begin{array}{l}\text { SDP } \\
1.5 \\
\end{array}$ & $2,71 \%$ & $0,13 \%$ & $V<5,0 \%$ & $\begin{array}{l}\text { SudahMemenvhi } \\
\text { Standar }\end{array}$ & $2,58 \%$ \\
\hline 6 & $\begin{array}{l}\text { SDP } \\
2.1 \\
\end{array}$ & $1,40 \%$ & $0,13 \%$ & $\mathrm{~V}<5,0 \%$ & $\begin{array}{l}\text { SudahMemenuhi } \\
\text { Standar } \\
\end{array}$ & $1.27 \%$ \\
\hline 7 & $\begin{array}{l}\text { SDP } \\
2.2 \\
\end{array}$ & $1,42 \%$ & $0,15 \%$ & $\mathrm{~V}<5,0 \%$ & $\begin{array}{l}\text { SudahMemenuhi } \\
\text { Standar } \\
\end{array}$ & $1,27 \%$ \\
\hline 8 & $\begin{array}{l}\text { SDP } \\
2.3 \\
\end{array}$ & $1,40 \%$ & $0,13 \%$ & $\mathrm{~V}<5,0 \%$ & $\begin{array}{l}\text { SudahMemenuhi } \\
\text { Standar } \\
\end{array}$ & $1,27 \%$ \\
\hline
\end{tabular}

\section{SIMPULAN}

Kandungan $T H D_{i}$ di Blue Point Bay Villa \& Spa sebelum menggunakan filter Hybrid sebesar $25,17 \%$ yang berarti tidak sesuai standar IEEE 519-1992 yang telah ditentukan yaitu sebesar $\leq 8 \%$.Nilai $T H D_{v}$ di Blue Point Bay Villa \& Spa sebesar 0,13 \% dimana kondisi tersebut masih memenuhi standar maksimum $T H D_{v}$ IEEE 519-1992 sebesar $\leq 5 \%$ untuk tegangan $\leq 69 \mathrm{kV}$. Kandungan $T H D_{i}$ di Blue Point Bay Villa \& Spa setelah penggunaan filter Hybrid memenuhi Standar IEEE 519-1992 yang telah ditentukan yaitu sebesar $\leq 8 \%$. 


\section{DAFTAR PUSTAKA}

[1] Dugan R.C; McGranaghan, M.F; Santoso; Beaty, H.W.2003. Electrical Power System Quality - Second Edition. USA : McGraw-Hill.

[2] Dugan, R.C; Rizy.2001. Harmonic Considerations for Electrical Distribution Feeders. National Technical Information service, Report No. ORNL/Sub/81-95011/4.

[3] Mielczarski, W.1997. Quality of Electricity Supply and Management of Network Losses. Melbourne : Puma Press Publishing and Printing.

[4] Suryajaya, a. 2011. Pengaruh total harmonic distortion (thd) pada suatu sistem. Semarang ; program studi teknik elektro jurusan teknologi industri universitas katolik soegijapranata.

[5] Septiawan, h. 2012. Penggunaan filter hibrid konfigurasi seri untuk memperbaiki kinerja filter pasif dalam upaya peningkatan pereduksian harmonisa pada sistem kelistrikan di rsup sanglah. Jimbaran :FT Elektro (UNUD)

[6] Suwardana, i.k. 2013. "simulasi penentuan penempatan filter aktif shunt untuk mendapatkan distorsi daya yang terkecil di blue point bay villa \& spa" (tugas akhir). Denpasar: Universitas Udayana.

[7] Alit Angga; Rinas; Antonius IBW, 2016. Analisa Pengaruh Pengoperasian Beban-beban Nonlinier Terhadap Distorsi harmonisa pada Blue Point Bay Villa \& Spa. Bukit-Jimbaran Badung : Teknik Elektro Universitas Udayana. 